\title{
Effect of Ply Thickness on Damage Development Behavior of Thermoplastic Woven Fabric Composites Using Spread Yarns
}

\author{
Fujimoto Mayu, Mukoyama Kazutaka *, Li Xingsheng, Hanaki Koushu, Kurashiкi Tetsusei \\ Graduate School of Engineering, Osaka University, 2-1 Yamadaoka, Suita, Osaka 565-0871, Japan
}

Received 31 March 2021; accepted for publication 12 July 2021

\begin{abstract}
FRTP is highly recyclable and suitable for mass production. In addition, by using the spread yarns treated in a wide and thin state as the woven structure, it is expected that the generation of voids at the time of impregnation will be reduced and the mechanical properties will be improved, and the impregnation time will be shortened. In this study, the effect of ply thickness on a damage development behavior of woven CFRTP using spread yarns was investigated by FEM based on damage mechanics. Firstly, finite element models of the woven structure with different ply thickness changed from the conventional yarns to the spread yarns were created. Secondary, as the material properties of the model, that of the UD material were applied to the fiber bundle, and the material nonlinear model based on stress dependence of the thermoplastic resin was applied to the matrix. Finally, damage development analysis was carried out on those models. As a result, it was clarified that the damage development behavior in the fiber bundle and in the matrix differs depending on the ply thickness.
\end{abstract}

Key Words : Woven CFRTP, Spread yarns, Damage development behavior, Material nonlinearity, Ply thickness, FEM

\section{開繊糸を用いた熱可塑性織物複合材料の 損傷進展挙動に及ぼす層厚の影響}

\author{
藤本真由, 向山和孝*, 李興盛, 花木宏修, 倉敷哲生
}

大阪大学大学院工学研究科

\section{1. 緒 言}

繊維強化複合材料 (FRP : Fiber Reinforced Plastic) は, 強化 材に繊維, 母材 (マトリックス) に樹脂を用いており, 高強度・ 高剛性などの優れた機械的特性に加えて, 優れた耐食性と構 造用材料としての軽量性を有する材料である. 特に, マトリッ クスに熱可塑性樹脂を用いた熱可塑性複合材料（FRTP：Fiber Reinforced Thermo Plastics) は, 樹脂が安価かつ短時間での成 形が可能であることから高い生産性を有し, 高勒性を示す上 にリサイクル性に優れている。 しかしながら, 熱可塑性樹脂 の粘度の高さから繊維間に樹脂を含浸させることが難しいと いう久点があった。 これに対し, 近年, 強化繊維束を幅方向 に広く，厚みを薄くした開繊糸を用いることにより，繊維束
の屈曲率や樹脂の含浸時のボイド発生を低減させ，機械的特 性の向上や含浸時間の短縮化が望める開繊技術 [1] が確立さ れた。熱可塑性樹脂などの高粘度マトリックスを用いる場合 は, この開繊工程が必要不可欠なものとなった。

一方, 繊維の強化形態には様々な形態が存在するが, その 中でも織物複合材料は, 繊維種, 樹脂種, 体積含有率, 織構 造など多くの設計パラメータを有する. そのため, 材料設計 において実験的に試験片の試作および評価を繰り返すこと は, 設計開発の長期化を招き,コストの増大に繋がる.さらに, 織物複合材料を一次構造材として用いる場合, 事前に機械的 特性や損傷機構を評価し把握しておくことは, 構造物の安全 性・信頼性を確保する上で非常に重要である。しかしながら, 開繊系を用いた織物複合材料の損傷評価においては, 厚みが

* 連絡先 : 大阪大学大学院工学研究科 565-0871 大阪府吹田市山田丘 2-1

E-mail : mukoyama@mit.eng.osaka-u.ac.jp, Tel : +81-6-6879-7564, Fax : +81-6-6879-7564 
非常に薄いことや複雑な繊維束の織構造に起因してマトリッ クスの樹脂き裂や繊維束内の樹脂き裂，繊維破断など様々な モードの損傷が発生するため容易ではない.

これらの問題には数值解析が有効であり, これまで様々な 研究がなされている。 上辻ら [2]は, 開繊 GF/VEの平織単 層材を対象に，層厚を $0.12 〜 0.36 \mathrm{~mm}$ まで変化させた織構 造モデルを用いて損傷力学に基づいた有限要素法による損傷 進展解析を行い，層厚の違いにより損傷進展挙動が異なるこ とを報告している. Pillai ら [3] は開繊 CF による織物積層材 を対象に異方性凝集フェーズフィールドモデルを用いてコン パクトテンション試験におけるき裂進展挙動および強度特性 を評価している。 また, Yang ら [4] は開繊 CF/EPのアング ルプライ平織積層材を対象に代表体積要素（RVE）を用いて 引張および圧縮の損傷進展挙動を評価しており，樋口ら [5] も織構造ではないが, 開繊 CF/EP のクロスプライ積層板を 対象に，0層をシェル要素で，90層を繊維/樹脂を区別し てソリッド要素でモデル化したRVE を構築し，さらに90 層の樹脂の材料非線形性に塑性モデルである双曲型 DruckerPrager モデルを用いることで損傷や強度特性の層厚依存性を 評価している。

このように数值解析を援用し, 開繊糸を用いた繊維強化複 合材料の損傷進展挙動の評価がなされており, 層厚は損傷進 展挙動に影響を及ぼすと考えられるが，本研究で対象とする 開繊糸を用いた熱可塑性織物複合材料については, 開繊糸の 織構造, さらには母材の材料非線形性までを考慮した層厚の 影響評価は十分にはなされていない，そこで本研究では，母 材の材料非線形性を考慮した開繊織物 CFRTP の積層材の損 傷進展解析を行い, 損傷進展挙動に及ぼす層厚の影響を調査 した。

\section{2. 解析方法}

\section{1 材料非線形性の適用}

本研究では座古ら [6] が提案した, 区間線形理論により応 力依存性に基づく弾性係数の近似式を適用することで熱可塑 性樹脂の材料非線形性を考慮する。この手法では弾性係数と して等価弾性係数を用いて以下に示す (1) 式で定義される. 仮想的な熱可塑性樹脂における近似式の材料定数を Table 1 に示し，その応力ーひずみ線図を Fig. 1 に示す.
Table 1 Material property by nonlinear approximation formula.

\begin{tabular}{|c|c|}
\hline$E_{i}$ & 3300 \\
\hline$\alpha$ & 14000 \\
\hline$n$ & 0.011 \\
\hline
\end{tabular}

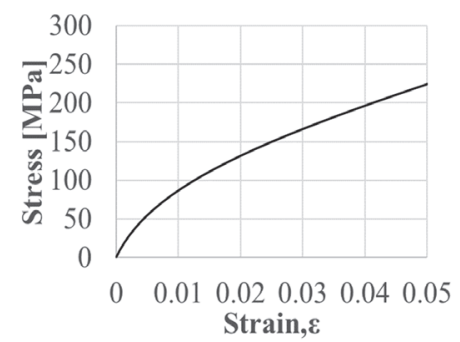

Fig. 1 Stress-strain curve by nonlinear approximation formula.

$$
E_{i}^{*}=E_{i}+\alpha_{i} e^{-n_{i} \sigma}
$$

ここで, $i$ は任意の方向, $E_{i}^{*}$ は等価弾性係数, $\sigma$ は応力, $E_{i}$, $\alpha_{i}, n_{i}$ は材料定数である.

\section{2 有限要素法に基づく損傷進展解析}

本研究では損傷の異方性を考慮した損傷力学に基づく有限 要素法 [7]に（1）式を実装し損傷進展解析を行う。損傷進展 解析では各要素の繊維束内に打ける損傷は, 材料主軸 $L-T-Z$ に対し垂直に発生するものと仮定し，Fig. 2 に示すように緎 維破断（Mode $L)$ およびマトリックスき裂（Mode $T \& L T$, Mode $Z$ \& $Z L$, Mode TZ) のいずれかの状態であるとする，こ こで, $L$ 軸は繊維配向方向， $T$ および $Z$ 軸は繊維直角方向を 意味する。要素の損傷判定には (2) 式で表される Hoffman 則 [8] を用いる. Hoffman 則では, 累積損傷值である $F$ 值が 1 を越えた時点で損傷発生と判定する. Hoffman 則により損傷 が発生したと判定された場合, 材料座標系の各方向の引張 り，圧縮およびせん断強度に対する発生応力の比により支配 的応力を決定して損傷モードを特定し，その力学的特性を Murakami [9] の 2 階損傷テンソルにより損傷状態における構 成則に反映し，剛性低下挙動を表現する.

$F=C_{1}\left(\sigma_{T}-\sigma_{Z}\right)^{2}+C_{2}\left(\sigma_{Z}-\sigma_{L}\right)^{2}+C_{3}\left(\sigma_{L}-\sigma_{T}\right)^{2}+C_{4} \sigma_{L}+C_{5} \sigma_{T}+C_{6} \sigma_{Z}+C_{7} \tau_{T Z}{ }^{2}+C_{8} \tau_{Z L}{ }^{2}+C_{9} \tau_{L T}^{2}$

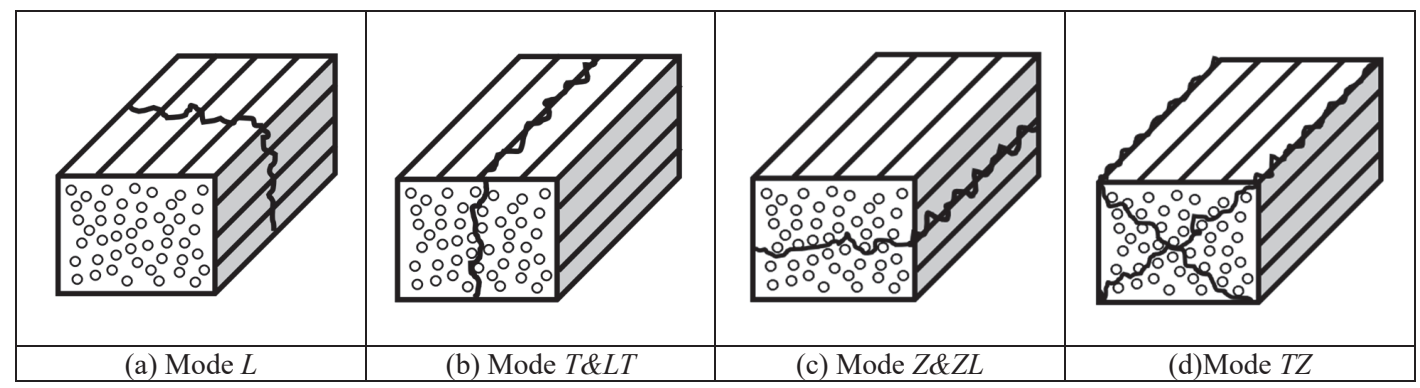

Fig. 2 Fracture Mode. 
ここで, $C_{i}(i=1 \sim 9)$ は, 基礎破壊強度から特定される材料 定数である.

\section{3 重合メッシュ法に基づく損傷進展解析}

本研究では後述するように層厚を $0.07 \mathrm{~mm} \sim 1.8 \mathrm{~mm}$ で変 化させた場合の損傷進展解析を行うが, 層厚がより小さい領 域（本研究では $0.07 \mathrm{~mm} \sim 0.10 \mathrm{~mm}$ ) における開繊織物複合 材料を解析する場合，マトリックスの樹脂部と複雑な形状を 有する繊維束の交差部の要素分割において, 解析結果に悪影 響を与える適切なアスペクト比を持たない歪んだ要素が発生 しやすいため，それを避けるための要素分割に労力が必要と なる。そこで，本研究では，マトリックスである樹脂の要素 分割と繊維束の要素分割をそれぞれ独立に行い, それらの有 限要素モデルを重ね合わせることで応力解析を実行できる重 合メッシュ法 $[10,11]$ を用いた。重合メッシュ法では, 全体 領域を表すグローバルモデルと内部に重ね合わせるローカル 領域を示すローカルモデルの 2 つをそれぞれ独立的に定義す る必要がある。重合メッシュ法による利点として, グローバ ルモデルとローカルモデルの相互の影響が定式化の中に反映 されているため, 精度の面においても優れるという点やグ ローバルモデルの内部であればローカルモデルは任意の位置 に重ね合わせることが出来るため, モデル作成やメッシュ作 成が容易という点が挙げられる。重合メッシュ法における剛 性方程式を(3) 式に示す.

$$
\left[\begin{array}{cc}
{\left[K^{G}\right]} & {\left[K^{G L}\right]} \\
{\left[K^{L G}\right]} & {\left[K^{L}\right]}
\end{array}\right]\left\{\begin{array}{l}
\left\{d^{G}\right\} \\
\left\{d^{L}\right\}
\end{array}\right\}=\left\{\begin{array}{c}
F^{S} \\
0
\end{array}\right\}
$$

ただし， $\left[K^{G}\right],\left[K^{L}\right]$ はそれぞれグローバルモデル，ローカル モデルにおける剛性マトリックス， $\left\{d^{G}\right\},\left\{d^{L}\right\}$ はそれぞれグ ローバルモデル，ローカルモデルにおける節点変位ベクトル， $\left\{F^{S}\right\}$ は荷重べクトルとする。 $\left[K^{G L}\right]$ と $\left[K^{L G}\right]$ で表される非対 角成分マトリックスは領域間の相関性を表し，この成分が重 合メッシュ法の特徴であり，2つのスケールを互いに連成す る。この重合メッシュ法を 2.2 節の損傷進展解析手法に実装 し, 損傷進展解析を行う.

\section{3．単層モデルの損傷進展挙動（開繊と従来 織の層厚変化の考慮)}

\section{1 解析モデル}

Fig. 3 に平織構造の単層モデルの有限要素モデルの一例を 示す. Fig. 3(a) はマトリックスと繊維束を同時に示したモデ ルを, Fig. 3(b) は繊維束のみを示したモデルを, Fig. 3(c) は 断面図をそれぞれ示す。ここで, Fig. 3(c)の $p$ および $t$ は単 層モデルの幅と層厚を， $w$ および $h$ は繊維束の幅と厚みをそ れぞれ示す。本解析では，体積を $175 \mathrm{~mm}^{3} \pm 1 \%$ 以内，繊維 体積含有率 $V_{f}$ を $50.6 \% \pm 1 \%$ 以内で一定にした条件下で，単 層モデルの層厚 $t$ を $0.1 \mathrm{~mm} \sim 1.8 \mathrm{~mm}$ まで変化させた 6 種類 の有限要素モデルを作成し, 境界条件と $z$ 方向に周期境界条 件を与えた. Table 2 に示すように Type A が最も層厚が薄く， 開繊されたモデルであり，Type $\mathrm{F} か ゙$ 最も層厚が厚く，従来 織に近いモデルとなっている。層厚が小さいモデルほど扁平 率が大きくなり，䋊維束のうねりが小さくなる。織構造の幾 何形状作成には, WiseTex[12] を使用し, MeshTex[13]でそ の幾何形状に基づき有限要素モデリングを行った。本研究で 用いた物性值を Table 3 に示す。また、マトリックスである 熱可塑性樹脂の材料非線形を考慮するために式（1）および Table 1 の物性值を用いた。単層の場合の 6 種類の有限要素モ デルはすべて要素数 8512, 節点数 10005 である.

Table 2 Dimensions of Type A Type F models in 1-ply.

\begin{tabular}{|l|l|l|l|l|}
\hline & $t(\mathrm{~mm})$ & $p(\mathrm{~mm})$ & $h(\mathrm{~mm})$ & $w(\mathrm{~mm})$ \\
\hline \multirow{2}{*}{ Type A } & 0.10 & 39.84 & 0.04 & 19.00 \\
\cline { 2 - 5 } & 0.10 & 43.90 & 0.04 & 21.00 \\
\hline \multirow{2}{*}{ Type B } & 0.20 & 28.13 & 0.08 & 12.85 \\
\cline { 2 - 5 } & 0.20 & 31.00 & 0.08 & 14.20 \\
\hline \multirow{2}{*}{ Type C } & 0.60 & 16.24 & 0.24 & 7.15 \\
\cline { 2 - 5 } & 0.60 & 17.90 & 0.24 & 7.90 \\
\hline \multirow{2}{*}{ Type D } & 0.90 & 13.25 & 0.36 & 5.79 \\
\cline { 2 - 5 } & 0.90 & 14.60 & 0.36 & 6.40 \\
\hline \multirow{2}{*}{ Type E } & 1.40 & 10.62 & 0.56 & 4.52 \\
\cline { 2 - 5 } & 1.40 & 11.70 & 0.56 & 5.00 \\
\hline \multirow{2}{*}{ Type F } & 1.80 & 9.35 & 0.72 & 3.98 \\
\cline { 2 - 5 } & 1.80 & 10.30 & 0.72 & 4.40 \\
\hline
\end{tabular}

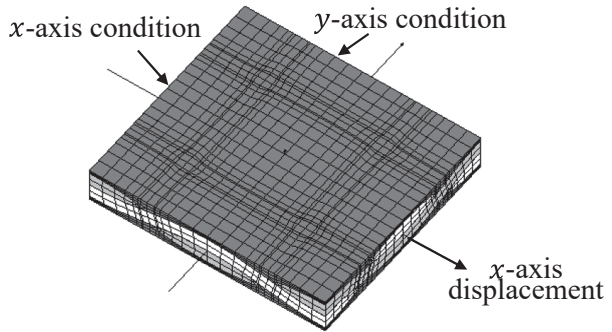

(a) Matrix and Fiber bundle

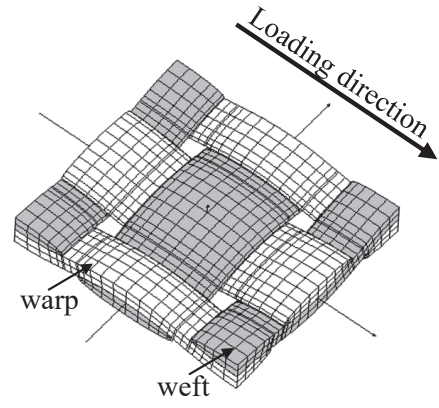

(b) Fiber bundle

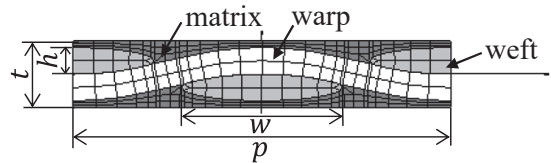

(c) Cross-section view

Fig. 3 Overview cross-section of finite elements. 
Table 3 Mechanical properties of Fiber bundle/Matrix.

\begin{tabular}{|c|c|c|c|}
\hline & & $\begin{array}{c}\text { Fiber bundle } \\
\text { (CF/PA6) }\end{array}$ & $\begin{array}{l}\text { Matrix } \\
\text { (PA6) }\end{array}$ \\
\hline \multirow{3}{*}{$\begin{array}{l}\text { Young's Modulus } \\
\text { [GPa] }\end{array}$} & $E_{L}$ & 228 & \multirow{3}{*}{2.70} \\
\hline & $E_{T}$ & 9.79 & \\
\hline & $E_{Z}$ & 9.79 & \\
\hline \multirow{3}{*}{$\begin{array}{l}\text { Shear modulus } \\
{[\mathrm{GPa}]}\end{array}$} & $G_{T Z}$ & 3.36 & \multirow{3}{*}{0.98} \\
\hline & $G_{Z L}$ & 4.45 & \\
\hline & $G_{L T}$ & 4.45 & \\
\hline \multirow{3}{*}{ Poisson's ratio } & $v_{T Z}$ & 0.46 & \multirow{3}{*}{0.38} \\
\hline & $v_{Z L}$ & 0.01 & \\
\hline & $v_{L T}$ & 0.31 & \\
\hline \multirow{3}{*}{$\begin{array}{c}\text { Tensile strength } \\
{[\mathrm{MPa}]}\end{array}$} & $F_{L}{ }^{t}$ & 3395 & \multirow{3}{*}{78.00} \\
\hline & $F_{T}{ }^{t}$ & 86.90 & \\
\hline & $F_{Z}{ }^{t}$ & 86.90 & \\
\hline \multirow{3}{*}{$\begin{array}{c}\text { Compressive strength } \\
{[\mathrm{MPa}]}\end{array}$} & $F_{L}{ }^{c}$ & 2957 & \multirow{3}{*}{88.00} \\
\hline & $F_{T}{ }^{c}$ & 98.00 & \\
\hline & $F_{Z}^{c}$ & 98.00 & \\
\hline \multirow{3}{*}{$\begin{array}{c}\text { Shear strength } \\
{[\mathrm{MPa}]}\end{array}$} & $F_{L T}$ & 49.02 & \multirow{3}{*}{54.40} \\
\hline & $F_{T Z}$ & 49.02 & \\
\hline & $F_{Z L}$ & 49.02 & \\
\hline
\end{tabular}

\section{2 解析結果}

\subsection{1＼cjkstart繊維束における損傷進展挙動}

Type A と Type F の Mode $T$ と Mode $Z L$ における損傷進展 挙動を Fig. $4 \sim$ Fig. 7 に示す. Type A 〜 Type D は, 横繊維 束内の Mode $T$ の損傷が初期に発生, 進展した。また, 層厚 が増すごとに Mode $Z L$ の損傷が発生するひずみが早くなっ た。そのため, Type E と Type F になると初期損傷では横繊 維束内の Mode $T$ と横繊維束交差部における Mode $Z L$ が発生 した。これは層厚の増加に伴いうねりの影響が大きくなるた め, 縦繊維束と横繊維束の交差部で発生したと考えられる. 以上より，層厚が小さいモデルほど初期損傷は横繊維束内の Mode $T$ の損傷から発生し, 層厚が大きくなるほど初期損傷 は横繊維束内の Mode $T$ と同時に縦繊維束と横繊維束の交差 部での Mode $Z L$ の損傷が発生することが明らかになった。

Fig. 8 に各層厚における各モードでのひずみと累積損傷体 積の関係を示す. Fig. 8(a) に示す横䋊維束内の Mode $T$ は層 厚が小さいほど累積の損傷体積が多く, Fig. 8(b)に示す縦繊 維束内の Mode $Z L$ と Fig. 8(c) に示す横繊維束内の Mode $Z L$

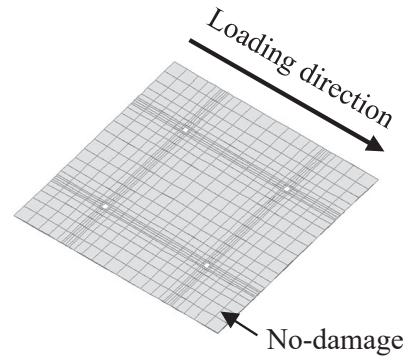

(a) $\varepsilon=0.50 \%$

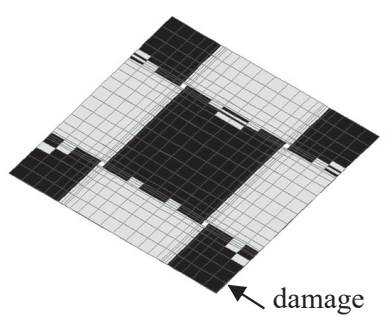

(b) $\varepsilon=1.00 \%$

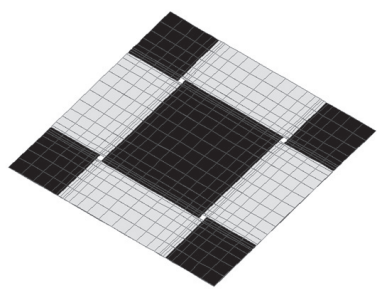

(c) $\varepsilon=1.50 \%$

Fig. 4 Damage development of Mode $T$ on Type A.

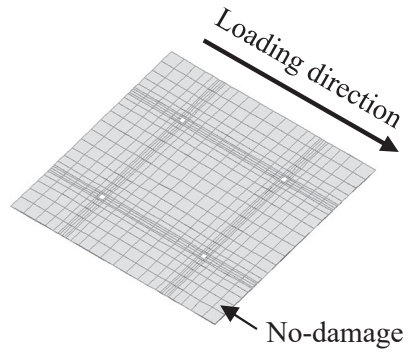

(a) $\varepsilon=0.50 \%$

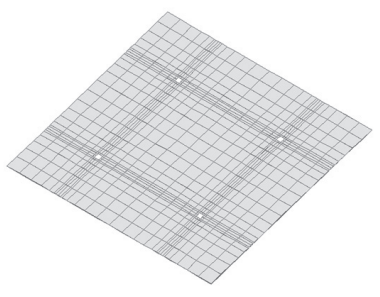

(b) $\varepsilon=1.00 \%$

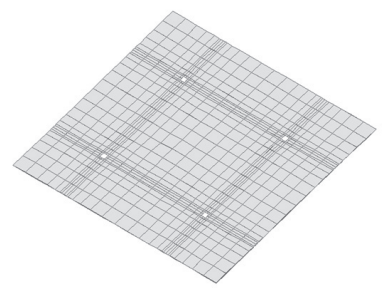

(c) $\varepsilon=1.50 \%$

Fig. 5 Damage development of Mode $Z L$ on Type A

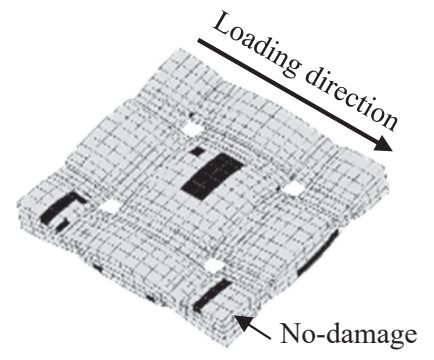

(a) $\varepsilon=0.51 \%$

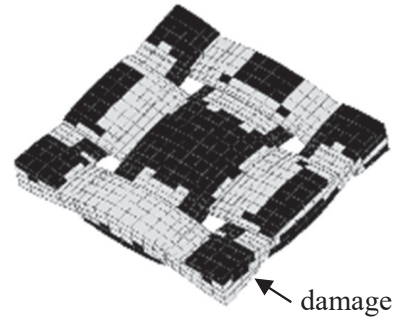

(b) $\varepsilon=1.01 \%$

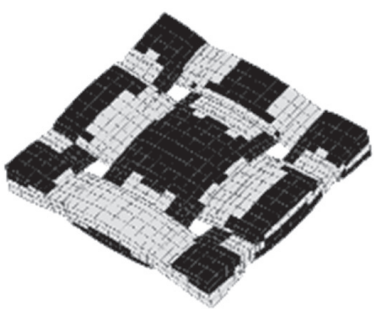

(c) $\varepsilon=1.51 \%$

Fig. 6 Damage development of Mode $T$ on Type F. 


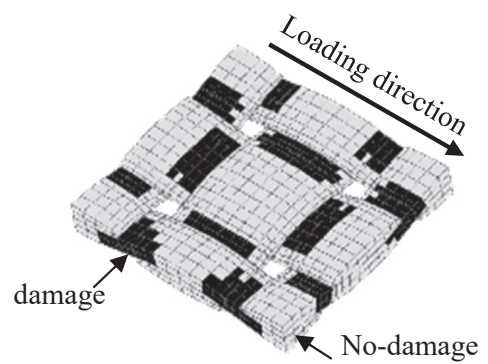

(a) $\varepsilon=0.51 \%$

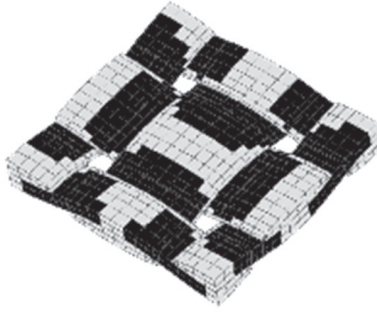

(b) $\varepsilon=1.01 \%$

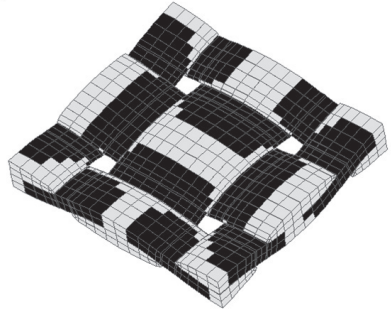

(c) $\varepsilon=1.51 \%$

Fig. 7 Damage development of Mode $Z L$ on Type F.

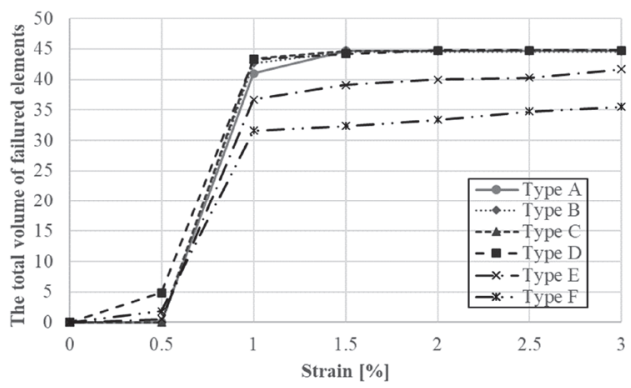

(a) Mode $T$ in weft

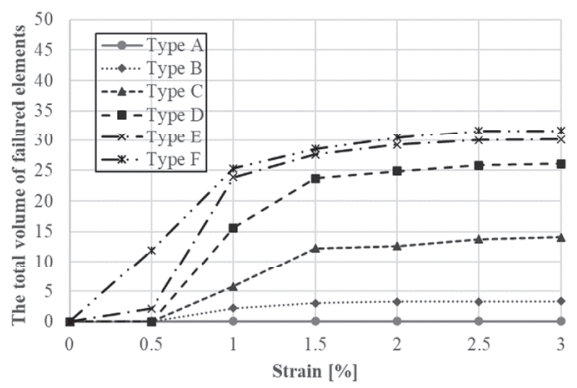

(b) Mode $Z L$ in warp

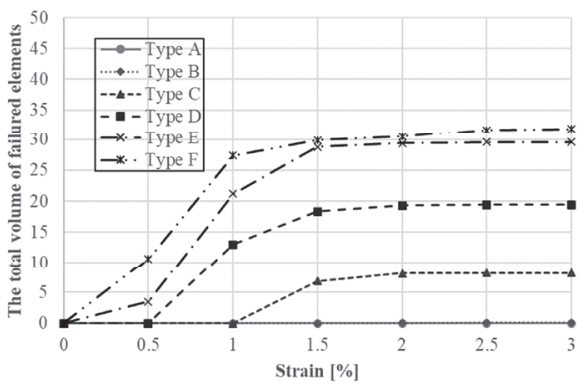

(c) Mode $Z L$ in weft

Fig. 8 Relationship between volume of damage elements and strain in 1-ply.
は層厚が大きいほど累積の損傷体積が多いという結果が得ら れた。以上より，層厚が小さい場合は縦繊維束と横繊維束の Mode $Z L$ が発生せずに，まず横繊維束内の Mode $T$ が発生し， その後破断に至る。それに対して層厚が大きい場合は縦繊維 束と横繊維束の Mode $Z L$ の損傷が最初に発生し, 次に横繊維 束内の Mode $T$ の損傷が起きる。 その後, 縦繊維束内の Mode $L$ が起因となって破断に至ると考える。つまり，厚みが小さ い場合は, 繊維束のうねりが小さいため負荷を縦繊維束の繊 維が主に受け持ち, 横繊維束内の繊維直角方向の樹脂き裂に よる損傷が発生した後，繊維破断が生じ破断に至る，厚みが 大きい場合は, 繊維束のうねりが大きいため, 負荷を繊維だ けでなくマトリックスも受け持ち, マトリックスでの損傷も 進展し, 繊維束のうねりの平滑化に伴い繊維束内の樹脂き裂 が発生，繊維破断が生じて破断に至る。

\subsection{2 マトリックスにおける損傷進展挙動}

次に単層モデルにおけるマトリックスの損傷進展挙動につ いて Fig. 9 およびFig. 10 に示す. Type B 〜 Type Fでは横繊 維束上の樹脂から損傷が発生し，ひずみが増加するにつれて 負荷方向に対して斜め方向に損傷が進展し, 面内せん断の影 響が支配的であった。一方, Type A では縦繊維束と横繊維束 が交差している負荷垂直方向端部からの損傷が見られ，その 後負荷垂直方向に支配的に損傷が進展した. Type A は層厚が 非常に薄いモデルであるため，繊維束自体のうねりの影響が 平滑化されるためと考える。 以上より，層厚により損傷進展 挙動が異なり, 層厚が大きくなると面内せん断方向の損傷進 展が支配的に, 層厚が小さくなると負荷垂直方向の損傷進展 が支配的となることが明らかとなった。

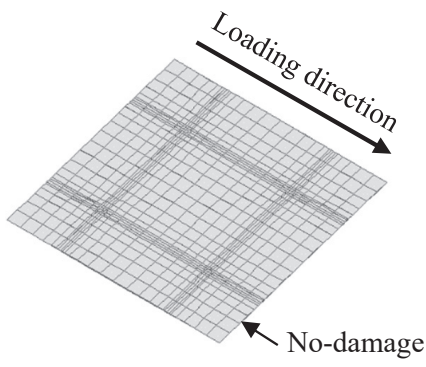

(a) $\varepsilon=1.50 \%$

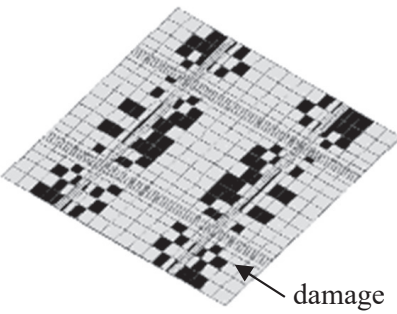

(b) $\varepsilon=2.01 \%$

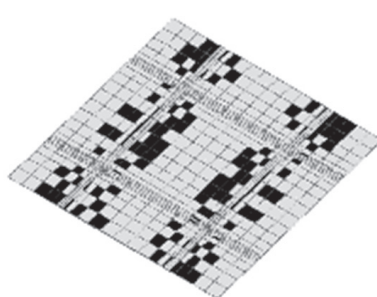

(c) $\varepsilon=2.50 \%$

Fig. 9 Damage development of Type A (matrix). 


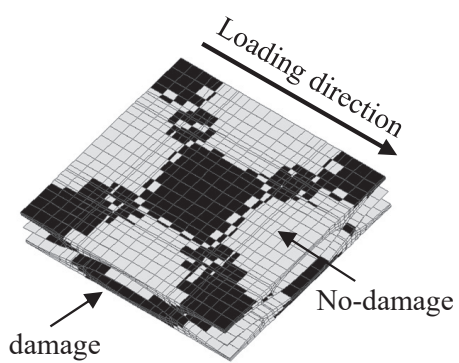

(a) $\varepsilon=1.50 \%$

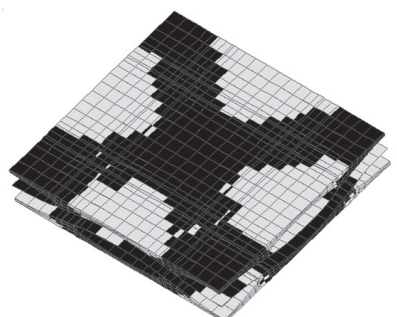

(b) $\varepsilon=2.00 \%$

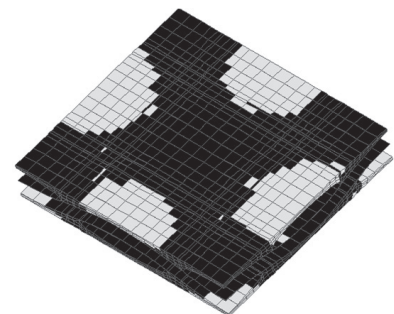

(c) $\varepsilon=2.50 \%$

Fig. 10 Damage development of Type F (matrix).

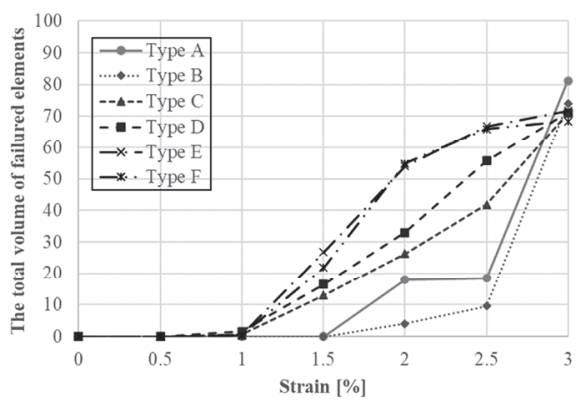

Fig. 11 Relationship between total volume of damage elements of matrix and strain in 1-ply.

次にひずみとマトリックスの累積の損傷体積との関係を表 した結果を Fig. 11 に示す。層厚が大きいほどマトリックス における累積の損傷体積が多い。これは，層厚が大きいほど マトリックスが負荷を受け持つため, 層厚が大きいほど損傷 体積が多くなっていると考えられる。

\section{4. 単層モデルを 2 層積層した場合の損傷進 展挙動（開繊の層厚変化の考慮）}

\section{1 解析モデル}

体積を $175 \mathrm{~mm}^{3} \pm 1 \%$ 以内, 繊維体積含有率 $V_{f}$ を $50.6 \% \pm$
Table 4 Dimensions of Type I Type III models in 2-ply.

\begin{tabular}{|c|c|c|c|c|}
\hline & $t(\mathrm{~mm})$ & $p(\mathrm{~mm})$ & $h(\mathrm{~mm})$ & $w(\mathrm{~mm})$ \\
\hline \multirow{2}{*}{ Type I } & 0.10 & 39.84 & 0.04 & 19.00 \\
\cline { 2 - 5 } & 0.10 & 43.90 & 0.04 & 21.00 \\
\hline \multirow{2}{*}{ Type II } & 0.08 & 44.47 & 0.03 & 20.81 \\
\cline { 2 - 5 } & 0.08 & 49.00 & 0.03 & 23.00 \\
\hline \multirow{2}{*}{ Type III } & 0.07 & 47.55 & 0.03 & 21.71 \\
\cline { 2 - 5 } & 0.07 & 52.40 & 0.03 & 24.00 \\
\hline
\end{tabular}

$1.1 \%$ 以内で一定にした条件下で, Table 4 に示すように単層 あたりの層厚を $0.1 \mathrm{~mm} \sim 0.07 \mathrm{~mm}$ まで変化させ， 2 層に積 層した 3 種類の有限要素モデルを作成した。なお, 本解析 では 2.2 節にて述べたように重合メッシュ法に基づく損傷進 展解析を適用した。 Type I が最も層厚が大きく, Type III が 最も層厚が小さいモデルである。またType I の寸法は 3 章 の Type A と等しい. グローバルモデルの境界条件は, 3 章と 同様の境界条件を与え, ローカルモデルの境界条件は, ロー カルモデルの表面節点に $\mathrm{x}, \mathrm{y}, \mathrm{z}$ 方向の完全拘束を与えてい る. 3 種類のすべてのグローバルモデルは要素数 1620 , 節点 数 2166 であり，すべてのローカルモデルは要素数 4928, 節 点数 8468 となっている.

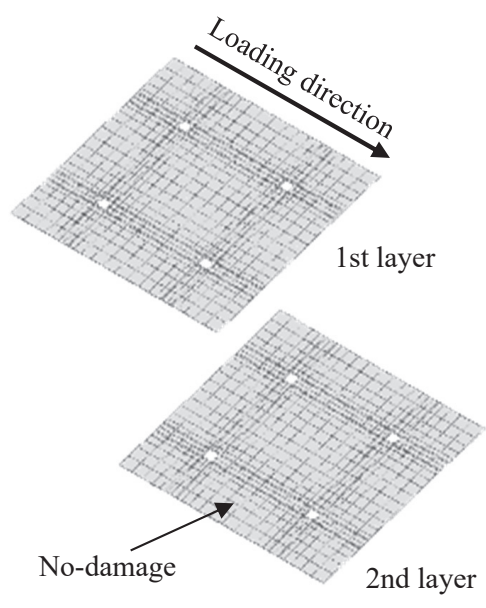

(a) $\varepsilon=0.51 \%$

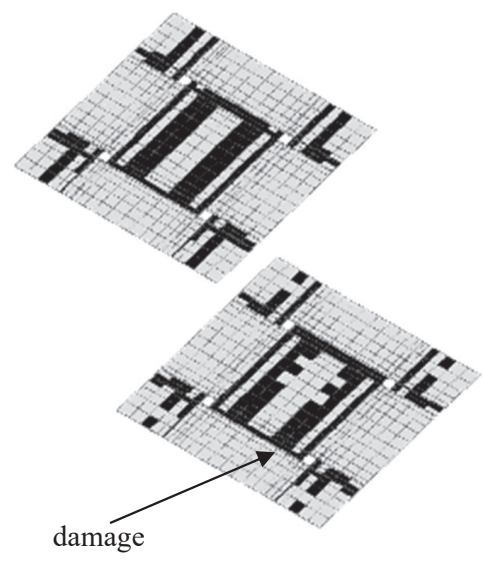

(b) $\varepsilon=1.00 \%$

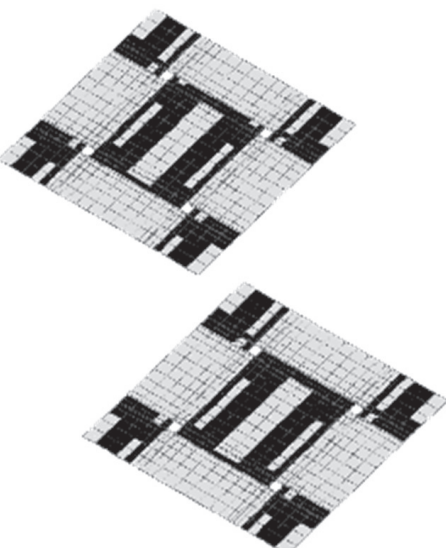

(c) $\varepsilon=1.51 \%$

Fig. 12 Damage development of Mode $T$ on Type III. 


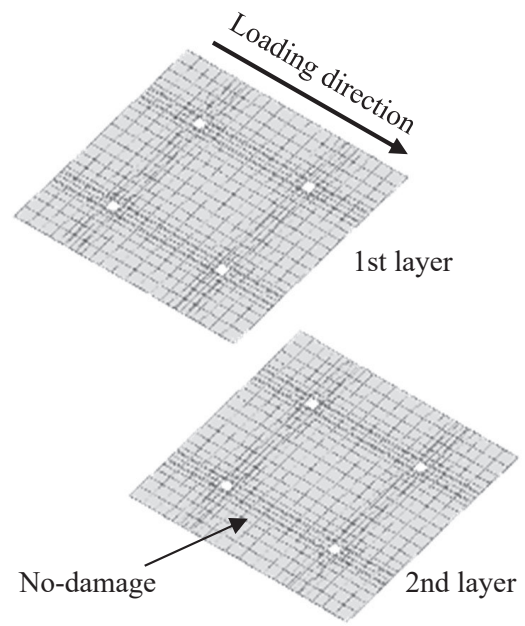

(a) $\varepsilon=0.51 \%$

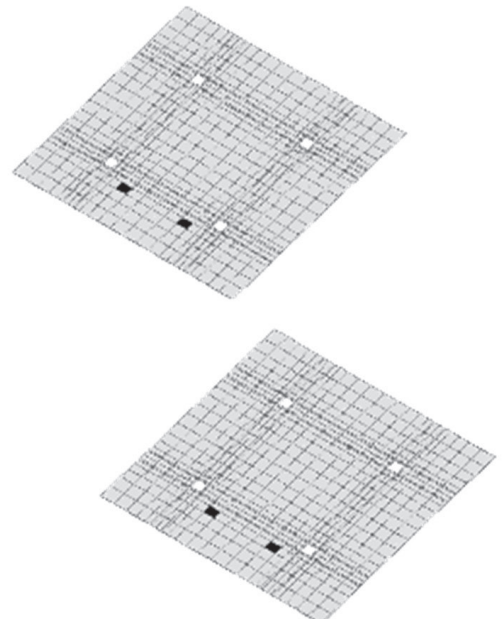

(b) $\varepsilon=1.00 \%$
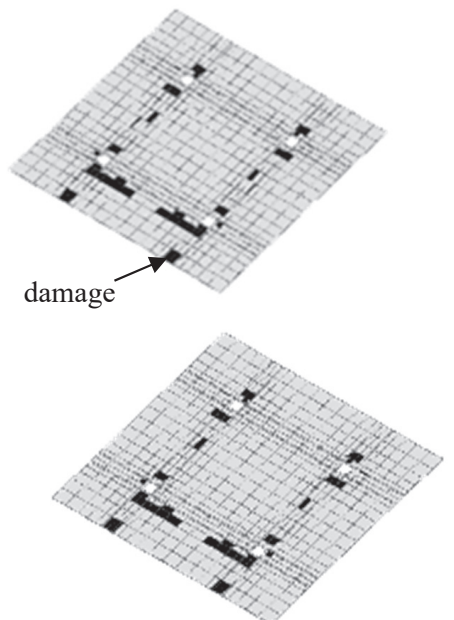

(c) $\varepsilon=1.51 \%$

Fig. 13 Damage development of Mode $Z L$ on Type III.

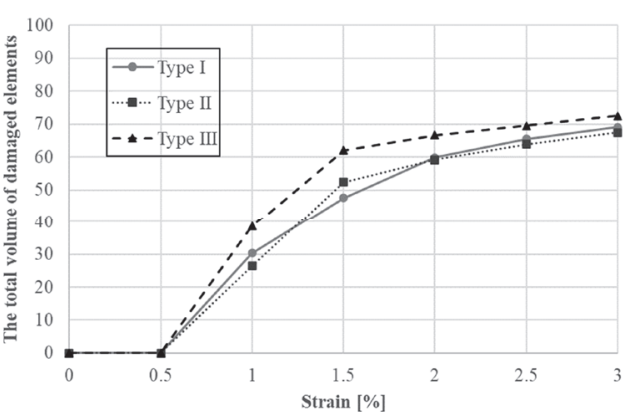

(a) Mode $T$ in weft

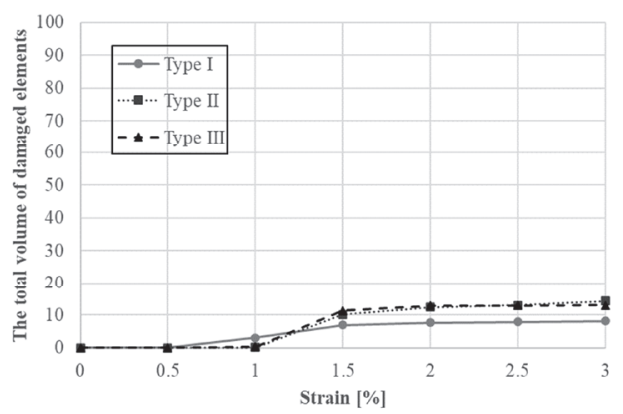

(b) Mode $Z L$ in warp

Fig. 14 Relationship between total volume of damage elements and strain in 2-ply.

\section{2 解析結果}

\subsection{1繊維束における損傷進展挙動}

Type III の Mode $T$ と Mode $Z L$ における損傷進展挙動を Fig. 12 および Fig. 13 に示す.すべてのモデルにおいて初期 損傷は横繊維束における Mode $T$ の損傷であり, その後横繊 維束内で損傷が進展した。 また, Mode $Z L$ の損傷は縦繊維束 と横繊維束の交差部付近に発生した.

次にひずみと累積の損傷体積に関する結果を Fig. 14 に示 す. Fig. 14(a) に示す横繊維束における Mode $T$ は Type III が 最も累積損傷体積が大きい結果となり, これは層厚が小さ くなるほど損傷体積が大きくなる 3 章の結果の傾向と一致す る. Fig. 14(b)に示す縦繊維束における Mode $Z L$ は Type A と 同様, 横繊維束における Mode $T$ に比べて累積の損傷体積が 少なかった。 また, 3 章の層厚の小さい結果と同様, 横繊維 束における Mode $Z L$ もほとんど発生していなかった。

\subsection{2 マトリックスにおける損傷進展挙動}

次に, 一例として Type III におけるマトリックスの損傷進 展挙動を Fig. 15 に示す.すべてのモデルにおいて縦繊維束

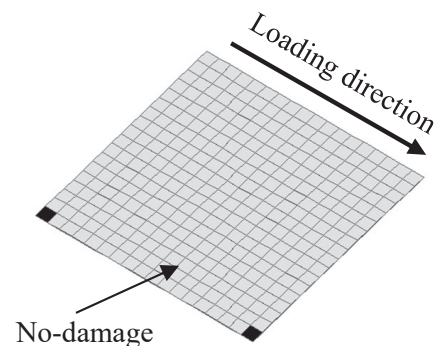

(a) $\varepsilon=1.51 \%$

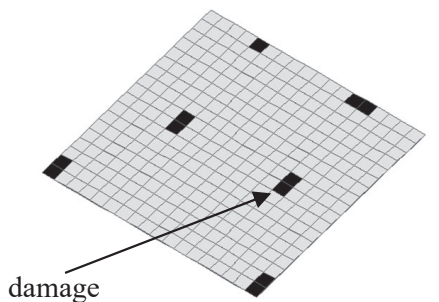

(b) $\varepsilon=2.00 \%$

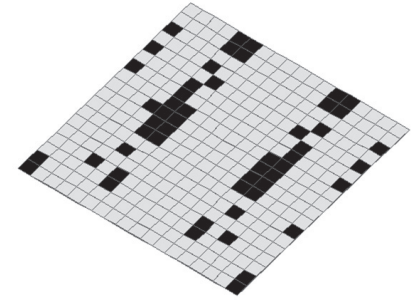

(c) $\varepsilon=2.51 \%$

Fig. 15 Damage development of Type III (matrix). 


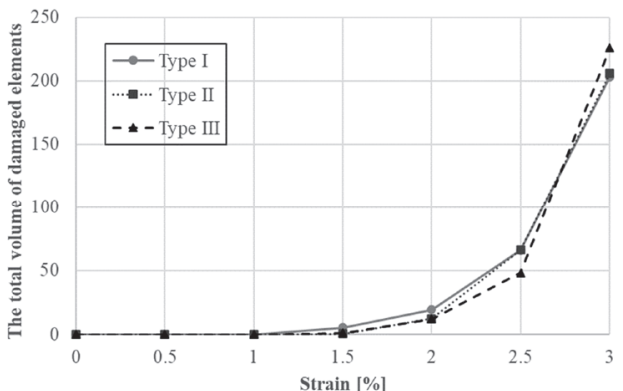

Fig. 16 Relationship between total volume of damage elements of matrix and strain in 2-ply.

と横繊維束が交差している負荷垂直方向端部からの損傷が見 られ，その後負荷垂直方向に損傷が進展した。これは 3 章の Type A と同じ現象である。 そのため, 3 章の結果と Fig. 15 の 結果より，層厚が小さくなるとマトリックスの損傷進展挙動 は層厚が大きい場合と異なると考えられる。

次にマトリックスにおけるひずみと累積の損傷体積との関 係を Fig. 16 に示す。ひずみが $2.7 \%$ までは層厚が小さくなる ほどマトリックスの損傷体積が小さくなる。これは 3 章のマ トリックスにおけるひずみと累積の損傷体積との関係におい て層厚が小さくなるほど損傷体積も小さくなるという結果と 一致している。

\section{5. 結 言}

本研究では母材の材料非線形性を考慮したメゾスケールの 開繊織物 CFRTP の積層材の損傷進展解析を行い, 損傷進展 挙動に及ぼす層厚の影響を調査した。得られた知見を以下に 示す.

（1）開繊と従来織の層厚変化による単層モデルの損傷進展挙 動について, Type A 〜 Type E の纎維束およびマトリックス の損傷結果から，層厚が小さい場合は，繊維束のうねりが小 さいため負荷を縦繊維束の繊維が主に受け持ち, 横繊維束内 の Mode $T$ の樹脂き裂による損傷が支配的に発生した。一方 で，層厚が大きい場合は，繊維束のうねりが大きいため，負 荷を繊維だけでなくマトリックスも受け持ち，マトリックス の損傷が面内せん断方向に支配的に進展し，繊維束のうねり の平滑化に伴い繊維束内の Mode $Z L$ の樹脂き裂が早期に発生 し，進展した。

(2) 開纎の層厚変化による単層モデルを 2 層積層した場合の 損傷進展挙動について，すべての層厚のモデルにおいて初 期損傷は横繊維束内の Mode $T$ の損傷であった。 また, Mode $Z L の$ 損傷は縦繊維束と横繊維束の交差部付近に発生した. マトリックスの損傷についても交差部の負荷垂直方向端部か らの損傷，進展がみられた。横繊維束内の Mode $T$ は Type III が最も累積損傷体積が大きい結果となり，単層材における結
果の傾向と一致した. Type I の縦繊維束内の Mode $Z L$ は，そ の単層材である Type A と同様，横繊維束における Mode $T$ に 比べて累積損傷体積は小さかった.

なお, 本研究の一部は日本繊維学会賞 学術研究奨励賞の 助成により遂行されたものである.

\section{References}

[1] Kawabe K (2002) Sen'i Kikai Gakkaishi (Journal of the Textile Machinery Society of Japan), 55, P416-P422 (in Japanese). https://doi.org/10.4188/transjtmsj.55.11_P416

[2] Uetsuji Y, Kurashiki T, Zako M (2004) Sen'i Kikai Gakkaishi (Journal of the Textile Machinery Society of Japan), 57, T13T19 (in Japanese). https://doi.org/10.4188/transjtmsj.57.T13

[3] Pillai U, Triantafyllou SP, Essa Y, de La Escalera FM (2020) Composite Structures, 252, 112635. https://doi.org/10.1016/ j.compstruct.2020.112635

[4] Yong C, Yinglong C, Zhenqiang Z, Peng L, Lu H, Chao Z (2020) Composite Structures, 234, 111701. https://doi. org/10.1016/j.compstruct.2019.111701

[5] Higuchi R, Aoki R, Yokozeki T, Okabe T (2020) Journal of the Japan Society for Composite Materials, 46, 212-222 (in Japanese)

[6] Zako M (1989) "Sutifukugouzairyorikigaku”, pp.13-14, Yokendo (in Japanese)

[7] Zako M, Takano N, Tsumura T (1996) Journal of the Society of Materials Science, Japan, 45, 117-122. https://doi. org/10.2472/jsms.45.6Appendix_117

[8] Hoffman O (1967) Journal of Composites Materials, 1, 200206. https://doi.org/10.1177/002199836700100210

[9] Murakami S (1988) Journal of Applied Mechanics, 55, 280286. https://doi.org/10.1115/1.3173673

[10] Fish J (1992) Computers \& Structures, 43, 539-547. https:// doi.org/10.1016/0045-7949(92)90287-A

[11] Kurashiki T, Lomov SV, Verpoest I (2018) Journal of Textile Engineering, 64, 83-91. https://doi.org/10.4188/jte.64.83

[12] Lomov SV, Huysmans G, Luo Y, Parnas R, Prodromou A, Verpoest I, Phelan FR (2001) Composites Part A: Applied Science and Manufacturing, 32, 1379-1394. https://doi. org/10.1016/S1359-835X(01)00038-0

[13] Hirosawa S, Kurashiki T, Nakai H, Zako M, Lomov SV, Verpoest I (2006) The proceedings of the JSME annual meeting, 541-542 (in Japanese). https://doi.org/10.1299/ jsmemecjo.2006.1.0_541

\section{文献}

[6] 座古勝 (1989) “数值複合材料力学”, pp.13-14, 養賢堂 